radically during the past ten years and the role of the profession in these new circumstances was discussed. While there is a general acceptance that the medical and veterinary professions have a great deal in common in teaching and research, the main divergence arises at the point of application to their respective patients. Economic considerations are of greatest influence in the poultry industry, where a setback in rearing birds may represent the difference between a profit and a loss ; there are similar considerations with all the farm animals and it is only with pet animals that sentiment replaces economic considerations. The diverse problems arising in controlling rabies were discuseed and a film was shown of clinical cases of rabies in dogs, cats and cattle. In North America there is a reservoir of infection in wild life-foxes, wolves, skunks-and relatively few cases in dogs. In Trinidad there is a vastly different problem where vampire and other bats act as reservoirs and the epizootic pattern in cattle varies with the disease position in colonies of bats. These colonies break up and disperse when furious rabies develops and causes infection in cattle in new areas. In Great Britain dogs and cats entering the country are held in quarantine for six months and it is clear that this is a small price to pay for freedom from this disease. There were three British veterinarians present who contributed to the proceedings. J. N. Ritchie, chief veterinary officer of Great Britain, presented a paper which surveyed the present position of the veterinary services in Britain, and W. L. Weipers, of the University of Glasgow, reviewed developments in veterinary education. D. D. Lawson, of the University of Glasgow, presented a paper on thoracic surgery and gave a televised demonstration of volatile anæsthesia in the cow and the dog.

This Convention provides a forum for the discussion of scientific and administrative matters which affect the profession in Canada. As Guelph is the alma mater of the majority of veterinarians who live in Canada, the meeting in this city also took on the character of an alumnus reunion and the social functions were very well attended.

\title{
CONTROL OF GOVERNMENT RESEARCH AND DEVELOPMENT EXPENDITURE IN BRITAIN
}

\begin{abstract}
$\mathrm{T}$ HE seventh special report from the Select Committee on Estimates for the session 1958-59* contains the observations of the Treasury on the sixth report from the Select Committee for the session 1957-58 dealing with Treasury control of expenditure (see Nature, 182, 1467 ; 1958). While the Treasury agrees with the Committee's general analysis and many of its comments on particular points, the Treasury suggests that in some respects the Committee's conclusions imply some misconceptions of what is needed, what is possible and what is in fact done. It is claimed that the theory of departmental responsibility and partnership has been steadily pursued under successive Governments for about forty years, and the Treasury does not agreo that, while new expenditure may be carefully watched, continuing expenditure may escape rela. tively unchallenged. Although the main responsibility for vigilant watching for economy in continuing expenditure rests, and must rest, with the spending Department, the Treasury does in fact supplement the Department's own efforts by maintaining a constant watch on continuing expenditure, as well as by bringing particular areas of such expenditure under special review from time to time. A high proportion of the Treasury's time is in fact devoted to considering such continuing expenditure.
\end{abstract}

On the Committee's suggestion that eventual commitments are inadequately assessed, the Treasury points out that a wide degree of uncertainty must often remain as to the eventual cost of research policies or major developments involving the solution of scientific and technical research problems; the comment is made that it is unrealistic to suppose that some alteration of financial technique in the Treasury could avoid such difficulties. Secondly, the Treasury

* Seventh Special Report from the Select Committee on Estimates Session 1958-59. Treasury Control of Expenditure (Observations of the Treas. points out that forecasts of all civil expenditure, up to three years ahead, have in fact been prepared annually for many years past, and play a very important part in the general control of Government expenditure. Without claiming that the technique of 'forward looks' is yet as fully developed or effectively exploited as it might be, the Treasury points out that Ministers are able to decide how far it is necessary to review existing policies reflected in the forecasts, and to adjust new policies which they may have had in mind, to contain the total of Government expenditure within acceptable limits. In devoting further attention to this matter, the Tressury undertakes, however, to have full regard to the Committee's comments. Again, while the Treasury agrees generally with the Committee as to the importance of prior sanction control, and also that the limits of delegated authority should be periodically reviewed as is at present done, it does not interpret the Committee's report as recommending in general any major change in the existing policy. It agrees with the Committee's view that delegation so far as is compatible with the reservation to the Chancellor of the Exchequer of the power to discharge effectively his own essential responsibilities is primarily an attitude of mind which should lead to action whenever opportunity offers ; but the three criteria suggested by the Select Committee in this connexion are regarded neither as a complete guide nor, within the ground they cover, as a wholly reliable one.

The Select Committee on Estimates had recommended specifically that a small independent committee, which should have access to Cabinet papers, should be appointed to report upon the theory and practice of Treasury control of expenditure. This recommendation the Treasury does not accept, and the report sets forth at some length the reasons why the Government is not prepared to accept the recommendation; although in view of the Committee's 
observations, the Government is initiating an internal inquiry, to be conducted under the general authority of the Chancellor of the Exchequer, into the principles and practice which govern the control by the executive of public expenditure. The conclusions reached by the Government will be reported to Parliament in due course.

The Treasury recognizes that the operation of Treasury control should be under constant review, but it does not consider that a review by an outside committee would be useful, partly because it would involve, in effect, a review of the Chancellor's conception of his own responsibilities, and partly because it would probably be found that a review of this kind would need to be extended beyond the Treasury itself into Parliamentary practice and into the financial control exercised by each major Department of State. The Treasury submits that it would be inappropriate for the Government to seek recommendations on Parliamentary practice from a body independent of Parliament, and that a realistic appraisal of the Government's financial control involves also consideration of the working of the central processes of government. It would also be inappropriate, the Treasury believes, for an independent committee to scrutinize and pronounce on the inner counsels of Government or on the resulting decisions, for which the Government is responsible to Parliament alone.

Some reservations may be entertained on these points ; but so far as the scientist or technologist is concerned, comment may well be left until the committee inquiring into the methods of managing and controlling research and development projects, of which Sir Solly Zuckerman has now succeeded the late Sir Claud Gibb as chairman, reports in due course. It should suffice to note meanwhile that the Treasury is very conscious of the need for strengthening and developing, on the right lines, the control, whether by the Treasury or by Departments, of expenditure on research and development, and is in broad agreement with the Committee's observa. tions on these matters. Discussions of which the subcommittee was informed in evidence have already resulted in agreed arrangements, which it is hoped will prove satisfactory in practice, for the closer association of the Treasury with work on defence research and development programmes.

\section{THE U.S. NATIONAL ACADEMY OF SCIENCES-NATIONAL RESEARCH COUNCIL, 1957-58}

$\mathrm{T}_{\mathrm{s}}^{\mathrm{H}}$ HE report of the U.S. National Academy of Sciences-National Research Council for 195758 (Washington, D.C. : National Academy of Sciences-National Research Council, 1959), published with the President's review and the report of the Treasurer, covers briefly the work during the year of the eight divisions of the Council, of the United States National Committee for the International Geophysical Year, and of the Office of International Relations and the Office of Scientific Personnel. The president, Dr. D. W. Bronk, points out that the operating budget of the Academy is now about $10 \cdot 6$ million dollars, an increase of 3.5 millions on 1956-57, and two-thirds of its direct expenditure came from federal agencies. A major undertaking (at the request of the Air Research and Development Command) of the year was a study of the scientific and technological future of the Air Force, while the Council's Highway Research Board is now responsible for conducting the American Association of State Highway Officials Road Test at a cost of more than 20 million dollars. The Committee on Meteorology, formed two years ago, has completed its study of how meteorology could be furthered, with reference to the needs of the Weather Bureau, and has proposed the establishment of a National Institute of Atmospheric Research. During the year a Committee on Oceanography was organized and the Division of Mathematics, with the assistance of the National Science Foundation, completed its survey of research potential and training in the mathematical sciences. At the request of the Secretary of Commerce the Academy is organizing a committee to evaluate the functions and operations of the Department in relation to national needs, with especial reference to the National Bureau of Standards, the Weather Bureau, Patent Office and Office of Tech. nical Services.
Among miscellaneous activities of the Council not assigned to a division, the report notes those of the Advisory Board on Education, which has given special attention to improving the education of teachers and to studies of science curricula and courses, the committees concerned with the study of the biological effects of atomic radiation, the establishment in February 1958 of a Committee on Polar Research and the work of the Space Science Board, which held its first meeting in June 1958, and is studying the opportunities for scientific research opened up by the advent of modern satellites and rocket tools and their needs.

To a certain extent, some of the activities described in this report, such as those of the United States National Committee for the International Geophysical Year and the Office of Scientific Personnel, are covered by the annual report of the National Science Foundation, from which they received financial support and need not here be further described. Of those of the Research Council's own eight divisions a few examples are selected for illustration. The Division of Anthropology and Psychology participated in some cross-disciplinary projects including a contract with the Air Force for a study of problems connected with bio-astronautics, under the supervision of the Division of Medical Sciences, and a conference on Psychological Research in Education. It is also administratively responsible for the Armed Forces-National Research Council Committee on Vision. The Division of Biology and Agriculture reports no new major projects. The Division of Chemistry and Chemical Technology at its annual meeting was concerned with international chemical affairs and the improvement of documentation in chemical literature but reports no outstanding activities of its units.

The Division of Earth Sciences rendered advisory services to the Federal Government through its 